Огляди літератури, оригінальні дослідження, погляд на проблему, випадок з практики, короткі повідомлення УдК 616.895.1-616.895.6

DOI 10.11603/1811-2471.2021.v.i1.11990

\title{
ГЕНДЕРНІ ТА ВІКОВІ ОСОБЛИВОСТІ ЯКОСТІ ЖИТТЯ ХВОРИХ НА ДЕПРЕСИВНІ РОЗЛАДИ
}

๑о. О. Белов

\section{Вінницький національний медичний університет імені М. І. Пирогова}

РЕзЮМЕ. Мета - дослідити особливості якості життя хворих на депресивні розлади з урахуванням гендерних та вікових особливостей.

Матеріал і методи. Клінічно обстежено 107 чоловіків і 138 жінок, хворих на депресивні розлади ендогенного характеру, з використанням методики оцінки якості життя Mezzich et al. в адаптації Н. О. Марути.

Результати. Хворим на депресивні розлади притаманні низька самооцінка якості життя (ЯЖ), особливо за сферами психологічного благополуччя, загального сприйняття життя, працездатності, особистісної реалізації та фізичного благополуччя. У жінок виявлено нижчі показники Яж за сферами фізичного благополуччя, психологічного благополуччя, самообслуговування і незалежності дій, працездатності, міжособистісної взаємодії та соціоемоційної підтримки, а також за інтегральними сферами суб' $є$ 'ктивного благополуччя/задоволеності та виконання соціальних ролей, і інтегральним показником ЯЖ. Оцінка ЯЖ фахівцем виявила вищі показники ЯЖ у чоловіків, при цьому значущими відмінності були лише за сферами духовної реалізації та загального сприйняття життя. Оцінка Яж фахівцем була у середньому в 1,5 рази вищою, ніж самооцінка хворими. 3 віком показники ЯЖ за всіма сферами погіршуються.

Висновки. Депресія супроводжується вираженим зниженням ЯЖ за всіма сферами, яке суб' єктивно тяжче сприймається жінками, але об' єктивно більше виражене у чоловіків; це погіршання стає більш вираженим з віком.

КлючовІ СловА: депресивні розлади; якість життя; гендерні; вікові особливості.

Вступ. Депресивні розлади є важливою медичною і соціальною проблемою $[1,2]$. Всесвітня організація охорони здоров'я (2018) оцінює кількість хворих на депресію у 264 млн осіб [3], великий депресивний розлад вважають третьою за масштабами тягаря хвороб нозологією; при цьому прогнозують, що до 2030 року це захворювання вийде на перше місце, випередивши інфекційні та серцево-судинні захворювання [4]. Депресія тісно пов'язана з автодеструктивною поведінкою, високим рівнем коморбідності та скороченням тривалості життя хворих $[5,6]$. Депресивні розлади супроводжуються глибокими порушеннями соціального функціонування не лише самого хворого, а й його найближчого оточення, зокрема, через деформацію гомеостазу сімейної системи $[7,8]$. Останніми роками особлива увага приділяється питанням відновлення нормального соціального функціонування хворих, забезпечення їх реадаптації та ресоціалізації, а також пошуку напрямків зменшення десоціалізуючого впливу депресій $[9,10]$. У цьому контексті важливе значення має дослідження якості життя (ЯЖ) [11] хворих на депресивні розлади як комплексного індикатора їх біопсихосоціального функціонування; результати такого дослідження можуть бути використані для розробки сучасних методів реабілітації та профілактики депресій $[12,13]$.

Мета - дослідити особливості якості життя хворих на депресивні розлади з урахуванням гендерних та вікових особливостей за даними самооцінки та оцінки фахівцем.

Матеріал і методи дослідження. 3 дотриманням принципів біомедичної етики на підставі інформованої згоди нами було клінічно обстежено 245 хворих на депресивні розлади (107 чоловіків і 138 жінок), які зверталися за психіатричною допомогою до Вінницької обласної психоневрологічної лікарні імені академіка О. І. Ющенка та за консультативно-лікувальною допомогою на кафедру медичної психології та психіатрії Вінницького національного медичного університету імені М. І. Пирогова впродовж 2015-2019 років. Критерієм Включення до дослідження було встановлення діагнозу депресивного розладу відповідно до критеріїв MKX-10 (коди F 31.3, F 31.4, F 32.0, F 32.1, F 32.2, F 33.0, F 33.1, F 33.2). Середній вік обстежених хворих склав $(33,6 \pm 11,2)$ років (медіана 33,0 років, інтерквартильний діапазон 22,0-42,0 роки), чоловіків - $(34,2 \pm 11,1)$ років $(34,0$ роки, 23,0-42,0 роки), жінок - $(33,2 \pm 11,4)$ років $(33,0$ роки, 22,0-41,0 рік) ( $>0,05)$. Середня тривалість захворювання на момент обстеження склала $(5,0 \pm 5,6)$ років $(4,0$ роки; 0,0-8,0 року), у чоловіків - $(5,7 \pm 5,8)$ років $(4,0$ роки, 0,0-9,0 років), у жінок - $(4,5 \pm 5,4)$ роки $(2,0$ роки; $0,0-7,0$ років) ( $p>0,05)$. Усі обстежені були поділені на три групи залежно від віку на момент обстеження: до 30 років (89 осіб: 38 чоловіків і 51 жінка), 30-44 роки (99 осіб: 46 чоловіків і 53 жінки), та 45 років і старші (57 осіб: 23 чоловіки і 34 жінки). Обстеження проведено з використанням методики оцінки якості життя Mezzich et al. (1999) в адаптації Н. О. Марути (2001) [14]. Оцінку характеру розподілу кількісних ознак проводили за допомогою тесту Шапіро-уїлка. Міжгруповий аналіз розбіжностей проводили за допомогою непараметричного тесту Манна-Уїтні. Прийнятним вважали рівень статистичної значущості понад $95 \%(p<0,05)$. 
Огляди літератури, оригінальні дослідження, погляд на проблему, випадок з практики, короткі повідомлення

Результати й обговорення. Кількісні показники ЯЖ у чоловіків і жінок, хворих на депресивні розлади, наведено у таблиці 1.

Як видно з таблиці, самооцінка ЯЖ хворими на депресивні розлади $\epsilon$ низькою за всіма сферами. Найнижчі показники самооцінки виявлено у сферах психологічного (емоційного) благополуччя, загального сприйняття життя, працездатності, особистісної реалізації та фізичного благополуччя, найвищі - за сферами громадської і службової підтримки та духовної реалізації. Показники за інтегральними сферами (суб'єктивного благополуччя/задоволеності, виконання соціальних ролей та зовнішніх життєвих умов) та інтегральний показ- ник ЯЖ у досліджених хворих також $\epsilon$ низькими. При цьому показники самооцінки ЯЖ у чоловіків і жінок значуще відрізняються за сферами фізичного благополуччя ( $<<0,01)$, психологічного (емоційного) благополуччя ( $<<0,01)$, самообслуговування і незалежності дій $(p<0,01)$, працездатності $(p<0,05)$, міжособистісної взаємодії $(p<0,01)$ та соціоемоційної підтримки ( $<<0,01)$, а також за інтегральними сферами суб'єктивного благополуччя/задоволеності $(p<0,01)$ та виконання соціальних ролей $(p<0,01)$, і за інтегральним показником ЯЖ $(p<0,01)$. При цьому загальною тенденцією є нижчі показники ЯЖ у жінок, порівняно з чоловіками, за всіма сферами, за винятком сфери духовної реалізації.

Таблиця 1. Показники якості життя у чоловіків і жінок, хворих на депресивні розлади

\begin{tabular}{|c|c|c|c|c|c|c|}
\hline \multirow{3}{*}{ Сфера якості життя } & \multicolumn{6}{|c|}{ Показник якості життя, $\mathrm{M} \pm \mathrm{m} / \mathrm{Me} /\left(\mathrm{Q}_{25}-\mathrm{Q}_{75}\right)$, бали } \\
\hline & \multicolumn{3}{|c|}{ за даними самооцінки } & \multicolumn{3}{|c|}{ за даними оцінки фахівця } \\
\hline & чоловіки & жінки & $p$ & чоловіки & жінки & $p$ \\
\hline $\begin{array}{l}\text { Фізичне } \\
\text { благополуччя }\end{array}$ & $\begin{array}{c}2,87 \pm 1,39 / 3,00 \\
(2,00-4,00)\end{array}$ & $\begin{array}{c}2,30 \pm 1,44 / 2,00 \\
(1,00-3,00)\end{array}$ & 0,001 & $\begin{array}{c}4,30 \pm 2,44 / 4,00 \\
(2,00-7,00)\end{array}$ & $\begin{array}{c}4,76 \pm 2,53 / 5,00 \\
(2,00-7,00)\end{array}$ & 0,180 \\
\hline $\begin{array}{l}\text { Психологічне } \\
\text { (емоційне) } \\
\text { благополуччя } \\
\end{array}$ & $\begin{array}{c}2,21 \pm 0,93 / 2,00 \\
(2,00-3,00)\end{array}$ & $\begin{array}{c}1,82 \pm 0,89 / 2,00 \\
(1,00-2,00)\end{array}$ & 0,001 & $\begin{array}{c}2,42 \pm 1,34 / 2,00 \\
(1,00-4,00)\end{array}$ & $\begin{array}{c}2,73 \pm 1,43 / 3,00 \\
(1,00-4,00)\end{array}$ & 0,098 \\
\hline $\begin{array}{l}\text { Самообслуговування } \\
\text { і незалежність дій }\end{array}$ & $\begin{array}{c}3,32 \pm 1,43 / 3,00 \\
(2,00-4,00)\end{array}$ & $\begin{array}{c}2,74 \pm 1,57 / 2,00 \\
(1,00-4,00)\end{array}$ & 0,001 & $\begin{array}{c}4,15 \pm 1,99 / 5,00 \\
(2,00-6,00)\end{array}$ & $\begin{array}{c}4,60 \pm 2,11 / 5,00 \\
(3,00-6,00)\end{array}$ & 0,066 \\
\hline Працездатність & $\begin{array}{c}2,30 \pm 1,07 / 2,00 \\
(1,00-3,00)\end{array}$ & $\begin{array}{c}2,01 \pm 1,22 / 2,00 \\
(1,00-3,00)\end{array}$ & 0,014 & $\begin{array}{c}3,23 \pm 1,54 / 3,00 \\
(2,00-5,00)\end{array}$ & $\begin{array}{c}3,58 \pm 1,53 / 3,00 \\
(3,00-5,00)\end{array}$ & 0,065 \\
\hline $\begin{array}{l}\text { Міжособистісна } \\
\text { взаємодія }\end{array}$ & $\begin{array}{c}4,01 \pm 1,56 / 4,00 \\
(3,00-5,00)\end{array}$ & $\begin{array}{c}3,33 \pm 1,70 / 3,00 \\
(2,00-5,00) \\
\end{array}$ & 0,001 & $\begin{array}{c}5,59 \pm 1,36 / 6,00 \\
(5,00-7,00)\end{array}$ & $\begin{array}{c}5,80 \pm 1,40 / 6,00 \\
(5,00-7,00)\end{array}$ & 0,263 \\
\hline $\begin{array}{l}\text { Соціоемоційна } \\
\text { підтримка }\end{array}$ & $\begin{array}{c}4,00 \pm 1,99 / 4,00 \\
(2,00-6,00)\end{array}$ & $\begin{array}{c}3,32 \pm 2,10 / 3,00 \\
(2,00-4,00)\end{array}$ & 0,003 & $\begin{array}{c}6,87 \pm 1,69 / 7,00 \\
(6,00-8,00)\end{array}$ & $\begin{array}{c}7,14 \pm 1,71 / 8,00 \\
(6,00-9,00)\end{array}$ & 0,204 \\
\hline $\begin{array}{l}\text { Громадська і } \\
\text { службова підтримка }\end{array}$ & $\begin{array}{c}6,36 \pm 1,50 / 6,00 \\
(5,00-8,00) \\
\end{array}$ & $\begin{array}{c}6,34 \pm 1,91 / 7,00 \\
(5,00-8,00) \\
\end{array}$ & 0,709 & $\begin{array}{c}8,54 \pm 2,63 / 10,00 \\
(8,00-10,00) \\
\end{array}$ & $\begin{array}{c}8,83 \pm 2,32 / 10,00 \\
(9,00-10,00)\end{array}$ & 0,572 \\
\hline $\begin{array}{l}\text { Особистісна } \\
\text { реалізація }\end{array}$ & $\begin{array}{c}2,85 \pm 1,34 / 3,00 \\
(2,00-4,00)\end{array}$ & $\begin{array}{c}2,78 \pm 1,37 / 2,00 \\
(2,00-4,00)\end{array}$ & 0,576 & $\begin{array}{c}5,33 \pm 1,34 / 6,00 \\
(5,00-6,00)\end{array}$ & $\begin{array}{c}5,59 \pm 1,39 / 6,00 \\
(5,00-7,00)\end{array}$ & 0,143 \\
\hline Духовна реалізація & $\begin{array}{c}4,58 \pm 1,73 / 5,00 \\
(3,00-6,00)\end{array}$ & $\begin{array}{c}4,66 \pm 1,83 / 5,00 \\
(3,00-6,00)\end{array}$ & 0,676 & $\begin{array}{c}6,84 \pm 1,37 / 7,00 \\
(6,00-8,00)\end{array}$ & $\begin{array}{c}7,30 \pm 1,54 / 7,00 \\
(6,00-9,00)\end{array}$ & 0,011 \\
\hline $\begin{array}{l}\text { Загальне сприйняття } \\
\text { життя }\end{array}$ & $\begin{array}{c}2,27 \pm 1,58 / 1,00 \\
(1,00-3,00)\end{array}$ & $\begin{array}{c}1,90 \pm 1,05 / 2,00 \\
(1,00-2,00)\end{array}$ & 0,385 & $\begin{array}{c}4,12 \pm 1,12 / 4,00 \\
(3,00-5,00)\end{array}$ & $\begin{array}{c}4,42 \pm 1,22 / 5,00 \\
(4,00-5,00)\end{array}$ & 0,022 \\
\hline $\begin{array}{l}\text { Суб'єктивне } \\
\text { благополуччя/ } \\
\text { задоволеність }\end{array}$ & $\begin{array}{c}7,35 \pm 3,15 / 7,00 \\
(5,00-10,00)\end{array}$ & $\begin{array}{c}6,02 \pm 2,79 / 5,00 \\
(4,00-8,00)\end{array}$ & 0,000 & $\begin{array}{c}10,84 \pm 4,61 / 10,00 \\
(6,00-16,00)\end{array}$ & $\begin{array}{c}11,91 \pm 4,91 / 12,00 \\
(7,00-16,00)\end{array}$ & 0,083 \\
\hline $\begin{array}{l}\text { Виконання } \\
\text { соціальних ролей }\end{array}$ & $\begin{array}{c}12,48 \pm 4,30 / 12,00 \\
(9,00-16,00)\end{array}$ & $\begin{array}{c}10,86 \pm 4,83 / 10,00 \\
(8,00-13,00)\end{array}$ & 0,002 & $\begin{array}{c}18,30 \pm 5,47 / 19,00 \\
(14,00-23,00)\end{array}$ & $\begin{array}{c}19,57 \pm 5,76 / 21,00 \\
(16,00-4,00)\end{array}$ & 0,076 \\
\hline $\begin{array}{l}\text { Зовнішні життєві } \\
\text { умови }\end{array}$ & $\begin{array}{c}14,93 \pm 4,57 / 15,00 \\
(11,00-19,00)\end{array}$ & $\begin{array}{c}14,32 \pm 5,01 / 14,50 \\
(11,00-18,00)\end{array}$ & 0,252 & $\begin{array}{c}22,25 \pm 4,90 / 23,00 \\
(20,0-26,0)\end{array}$ & $\begin{array}{c}23,27 \pm 4,59 / 25,00 \\
(21,0-27,0)\end{array}$ & 0,079 \\
\hline $\begin{array}{l}\text { Показник якості } \\
\text { життя }\end{array}$ & $\begin{array}{c}3,48 \pm 1,08 / 3,40 \\
(2,60-4,40)\end{array}$ & $\begin{array}{c}3,12 \pm 1,17 / 2,90 \\
(2,30-3,80)\end{array}$ & 0,007 & $\begin{array}{c}5,14 \pm 1,43 / 5,20 \\
(3,90-6,40)\end{array}$ & $\begin{array}{c}5,48 \pm 1,46 / 5,90 \\
(4,50-6,60)\end{array}$ & 0,071 \\
\hline
\end{tabular}

Показники ЯЖ хворих за оцінкою фахівця в середньому у 1,5 раза вищі, ніж самооцінка хворих; при цьому оцінки фахівця за сферою психологічного (емоційного) благополуччя найближчі до самооцінки хворих, а за сферами особистісної реалізації та загального сприйняття життя - най- більше відрізняються. У цілому оцінки яЖ фахівцем за ключовими сферами, що безпосередньо відображають вплив афективної симптоматики (психологічного (емоційного) благополуччя, працездатності), є низькими, тоді як сфери, де у хворого об'єктивних проблем немає (фізичного бла- 
Огляди літератури, оригінальні дослідження, погляд на проблему, випадок з практики, короткі повідомлення гополуччя, самообслуговування і незалежності дій, особистої реалізації, духовної реалізації), а також у сферах, які значною мірою залежать від мікросоціального оточення (соціоемоційна підтримка, громадська і службова підтримка) - вищими; саме у цих сферах виявлена найбільша дисоціація між самооцінкою ЯЖ хворими і оцінкою фахівцем. Цікаво, що за оцінкою фахівця показники ЯЖ у жінок за всіма сферами є вищими, порівняно з чоловіками, хоча статистично значущих розбіжностей тут суттєво менше, і вони менш виражені, ніж при самооцінці: лише за сферами духовної реалізації $(p<0,05)$ та загального сприйняття життя $(p<0,05)$.

При аналізі особливостей самооцінки ЯЖ хворими з урахуванням віку було виявлено, що показники ЯЖ за всіма сферами погіршуються 3 віком (табл. 2).

Таблиця 2. Показники якості життя у хворих на депресивні розлади різних вікових груп

\begin{tabular}{|c|c|c|c|c|c|c|}
\hline \multirow[t]{2}{*}{ Сфера якості життя } & \multicolumn{3}{|c|}{ Показник якості життя, $\mathrm{M} \pm \mathrm{m} / \mathrm{Me} /\left(\mathrm{Q}_{25}-\mathrm{Q}_{75}\right)$, бали } & \multicolumn{3}{|c|}{$\begin{array}{c}\text { Рівень статистичної } \\
\text { значущості розбіжностей (р) }\end{array}$} \\
\hline & до 30 років & 30-44 роки & 45 років і старші & $1-2$ & $1-3$ & $2-3$ \\
\hline 1 & 2 & 3 & 4 & 5 & 6 & 7 \\
\hline \multicolumn{7}{|c|}{ За даними самооцінки } \\
\hline $\begin{array}{l}\text { Фізичне } \\
\text { благополуччя }\end{array}$ & $\begin{array}{c}3,24 \pm 1,63 / 4,00 \\
(2,00-5,00)\end{array}$ & $\begin{array}{c}2,51 \pm 1,20 / 3,00 \\
(1,00-4,00)\end{array}$ & $\begin{array}{c}1,56 \pm 0,80 / 1,00 \\
(1,00-2,00)\end{array}$ & 0,001 & 0,000 & 0,000 \\
\hline $\begin{array}{l}\text { Психологічне } \\
\text { (емоційне) } \\
\text { благополуччя }\end{array}$ & $\begin{array}{c}2,49 \pm 1,10 / 3,00 \\
(2,00-3,00)\end{array}$ & $\begin{array}{c}1,83 \pm 0,67 / 2,00 \\
(1,00-2,00)\end{array}$ & $\begin{array}{c}1,47 \pm 0,57 / 1,00 \\
(1,00-2,00)\end{array}$ & 0,000 & 0,000 & 0,001 \\
\hline $\begin{array}{l}\text { Самообслуговування і } \\
\text { незалежність дій }\end{array}$ & $\begin{array}{c}3,80 \pm 1,60 / 4,00 \\
(2,00-5,00)\end{array}$ & $\begin{array}{c}2,70 \pm 1,42 / 2,00 \\
(2,00-4,00)\end{array}$ & $\begin{array}{c}2,25 \pm 0,99 / 2,00 \\
(2,00-3,00)\end{array}$ & 0,000 & 0,000 & 0,100 \\
\hline Працездатність & $\begin{array}{l}2,71 \pm 1,27 / 3,00 \\
(1,00-4,00)\end{array}$ & $\begin{array}{c}2,06 \pm 1,04 / 2,00 \\
(1,00-3,00)\end{array}$ & $\begin{array}{l}1,37 \pm 0,59 / 1,00 \\
(1,00-2,00)\end{array}$ & 0,000 & 0,000 & 0,000 \\
\hline $\begin{array}{l}\text { Міжособистісна } \\
\text { взаємодія }\end{array}$ & $\begin{array}{c}4,20 \pm 1,62 / 5,00 \\
(3,00-6,00)\end{array}$ & $\begin{array}{c}3,71 \pm 1,72 / 4,00 \\
(2,00-5,00)\end{array}$ & $\begin{array}{c}2,60 \pm 1,10 / 3,00 \\
(2,00-3,00)\end{array}$ & 0,053 & 0,000 & 0,000 \\
\hline $\begin{array}{l}\text { Соціоемоційна } \\
\text { підтримка }\end{array}$ & $\begin{array}{c}5,15 \pm 2,28 / 6,00 \\
(3,00-7,00)\end{array}$ & $\begin{array}{c}2,84 \pm 1,35 / 3,00 \\
(2,00-4,00)\end{array}$ & $\begin{array}{c}2,58 \pm 1,21 / 2,00 \\
(2,00-3,00)\end{array}$ & 0,000 & 0,000 & 0,273 \\
\hline $\begin{array}{l}\text { Громадська і } \\
\text { службова підтримка }\end{array}$ & $\begin{array}{c}6,97 \pm 1,41 / 7,00 \\
(6,00-8,00)\end{array}$ & $\begin{array}{c}6,24 \pm 1,70 / 6,00 \\
(5,00-8,00)\end{array}$ & $\begin{array}{c}5,56 \pm 1,93 / 6,00 \\
(4,00-7,00)\end{array}$ & 0,003 & 0,000 & 0,045 \\
\hline $\begin{array}{l}\text { Особистісна } \\
\text { реалізація }\end{array}$ & $\begin{array}{c}3,38 \pm 1,24 / 3,00 \\
(2,00-5,00)\end{array}$ & $\begin{array}{c}2,80 \pm 1,41 / 3,00 \\
(2,00-4,00)\end{array}$ & $\begin{array}{c}1,95 \pm 0,93 / 2,00 \\
(1,00-2,00)\end{array}$ & 0,002 & 0,000 & 0,000 \\
\hline Духовна реалізація & $\begin{array}{c}5,13 \pm 1,49 / 5,00 \\
(5,00-6,00)\end{array}$ & $\begin{array}{c}4,53 \pm 1,89 / 5,00 \\
(3,00-6,00) \\
\end{array}$ & $\begin{array}{c}4,00 \pm 1,81 / 4,00 \\
(3,00-5,00)\end{array}$ & 0,032 & 0,000 & 0,093 \\
\hline $\begin{array}{l}\text { Загальне сприйняття } \\
\text { життя }\end{array}$ & $\begin{array}{c}2,79 \pm 1,39 / 3,00 \\
(2,00-4,00)\end{array}$ & $\begin{array}{c}1,78 \pm 1,26 / 1,00 \\
(1,00-2,00)\end{array}$ & $\begin{array}{c}1,42 \pm 0,63 / 1,00 \\
(1,00-2,00)\end{array}$ & 0,000 & 0,000 & 0,267 \\
\hline $\begin{array}{l}\text { Суб'єктивне } \\
\text { благополуччя/ } \\
\text { задоволеність }\end{array}$ & $\begin{array}{l}8,52 \pm 3,44 / 9,00 \\
(5,00-12,00)\end{array}$ & $\begin{array}{l}6,11 \pm 2,11 / 6,00 \\
(4,00-7,00)\end{array}$ & $\begin{array}{l}4,46 \pm 1,52 / 4,00 \\
(3,00-5,00)\end{array}$ & 0,000 & 0,000 & 0,000 \\
\hline $\begin{array}{l}\text { Виконання соціальних } \\
\text { ролей }\end{array}$ & $\begin{array}{c}14,09 \pm 4,53 / 14,00 \\
(10,00-18,00)\end{array}$ & $\begin{array}{c}11,26 \pm 4,37 / 10,00 \\
(8,00-14,00)\end{array}$ & $\begin{array}{c}8,16 \pm 2,64 / 8,00 \\
(6,00-10,00)\end{array}$ & 0,000 & 0,000 & 0,000 \\
\hline $\begin{array}{l}\text { Зовнішні життєві } \\
\text { умови }\end{array}$ & $\begin{array}{c}17,25 \pm 4,27 / 18,00 \\
(15,00-20,00) \\
\end{array}$ & $\begin{array}{c}13,61 \pm 4,38 / 14,00 \\
(10,00-17,00) \\
\end{array}$ & $\begin{array}{c}12,14 \pm 4,49 / 12,00 \\
(9,00-16,00) \\
\end{array}$ & 0,000 & 0,000 & 0,061 \\
\hline $\begin{array}{l}\text { Показник якості } \\
\text { життя }\end{array}$ & $\begin{array}{c}3,99 \pm 1,09 / 4,10 \\
(3,00-4,90)\end{array}$ & $\begin{array}{c}3,10 \pm 0,97 / 3,10 \\
(2,50-3,80)\end{array}$ & $\begin{array}{c}2,48 \pm 0,78 / 2,40 \\
(2,00-3,10)\end{array}$ & 0,000 & 0,000 & 0,000 \\
\hline \multicolumn{7}{|c|}{ За даними оцінки фахівця } \\
\hline $\begin{array}{l}\text { Фізичне } \\
\text { благополуччя }\end{array}$ & $\begin{array}{c}5,76 \pm 2,10 / 6,00 \\
(4,00-8,00)\end{array}$ & $\begin{array}{c}4,40 \pm 2,51 / 4,00 \\
(2,00-7,00)\end{array}$ & $\begin{array}{c}2,95 \pm 2,05 / 2,00 \\
(2,00-4,00)\end{array}$ & 0,000 & 0,000 & 0,000 \\
\hline $\begin{array}{l}\text { Психологічне } \\
\text { (емоційне) } \\
\text { благополуччя }\end{array}$ & $\begin{array}{c}3,30 \pm 1,29 / 4,00 \\
(2,00-4,00)\end{array}$ & $\begin{array}{c}2,45 \pm 1,35 / 2,00 \\
(1,00-3,00)\end{array}$ & $\begin{array}{c}1,74 \pm 1,06 / 1,00 \\
(1,00-2,00)\end{array}$ & 0,000 & 0,000 & 0,001 \\
\hline $\begin{array}{l}\text { Самообслуговування і } \\
\text { незалежність дій }\end{array}$ & $\begin{array}{c}5,37 \pm 1,48 / 6,00 \\
(5,00-6,00)\end{array}$ & $\begin{array}{c}4,48 \pm 2,10 / 5,00 \\
(3,00-6,00)\end{array}$ & $\begin{array}{c}2,75 \pm 1,79 / 2,00 \\
(1,00-5,00)\end{array}$ & 0,003 & 0,000 & 0,000 \\
\hline Працездатність & $\begin{array}{c}4,13 \pm 1,26 / 4,00 \\
(3,00-5,00)\end{array}$ & $\begin{array}{c}3,37 \pm 1,49 / 3,00 \\
(2,00-5,00)\end{array}$ & $\begin{array}{c}2,42 \pm 1,45 / 2,00 \\
(1,00-3,00)\end{array}$ & 0,000 & 0,000 & 0,000 \\
\hline
\end{tabular}


Огляди літератури, оригінальні дослідження, погляд на проблему, випадок з практики, короткі повідомлення

Продовження табл. 2

\begin{tabular}{|c|c|c|c|c|c|c|}
\hline 1 & 2 & 3 & 4 & 5 & 6 & 7 \\
\hline $\begin{array}{l}\text { Міжособистісна } \\
\text { взаємодія }\end{array}$ & $\begin{array}{c}6,33 \pm 1,08 / 6,00 \\
(6,00-7,00)\end{array}$ & $\begin{array}{c}5,79 \pm 1,22 / 6,00 \\
(5,00-7,00)\end{array}$ & $\begin{array}{c}4,60 \pm 1,43 / 4,00 \\
(4,00-6,00)\end{array}$ & 0,002 & 0,000 & 0,000 \\
\hline $\begin{array}{l}\text { Соціоемоційна } \\
\text { підтримка }\end{array}$ & $\begin{array}{c}7,85 \pm 1,17 / 8,00 \\
(7,00-9,00) \\
\end{array}$ & $\begin{array}{c}7,02 \pm 1,58 / 7,00 \\
(6,00-8,00) \\
\end{array}$ & $\begin{array}{c}5,72 \pm 1,81 / 5,00 \\
(5,00-7,00) \\
\end{array}$ & 0,000 & 0,000 & 0,000 \\
\hline $\begin{array}{l}\text { Громадська і } \\
\text { службова підтримка }\end{array}$ & $\begin{array}{c}9,44 \pm 1,36 / 10,00 \\
(10,00-10,00)\end{array}$ & $\begin{array}{c}8,84 \pm 2,29 / 10,00 \\
(9,00-10,00)\end{array}$ & $\begin{array}{c}7,33 \pm 3,38 / 10,00 \\
(4,00-10,00)\end{array}$ & 0,111 & 0,000 & 0,009 \\
\hline $\begin{array}{l}\text { Особистісна } \\
\text { реалізація }\end{array}$ & $\begin{array}{c}6,26 \pm 0,92 / 6,00 \\
(6,00-7,00)\end{array}$ & $\begin{array}{c}5,51 \pm 1,13 / 6,00 \\
(5,00-6,00)\end{array}$ & $\begin{array}{c}4,21 \pm 1,44 / 4,00 \\
(3,00-5,00)\end{array}$ & 0,000 & 0,000 & 0,000 \\
\hline Духовна реалізація & $\begin{array}{c}7,87 \pm 1,34 / 8,00 \\
(7,00-9,00) \\
\end{array}$ & $\begin{array}{c}7,14 \pm 1,29 / 7,00 \\
(6,00-8,00) \\
\end{array}$ & $\begin{array}{c}5,82 \pm 1,15 / 6,00 \\
(5,00-7,00)\end{array}$ & 0,001 & 0,000 & 0,000 \\
\hline $\begin{array}{l}\text { Загальне сприйняття } \\
\text { життя }\end{array}$ & $\begin{array}{c}4,91 \pm 0,75 / 5,00 \\
(4,00-5,00) \\
\end{array}$ & $\begin{array}{c}4,32 \pm 1,00 / 4,00 \\
(4,00-5,00) \\
\end{array}$ & $\begin{array}{c}3,26 \pm 1,34 / 3,00 \\
(2,00-4,00)\end{array}$ & 0,000 & 0,000 & 0,000 \\
\hline $\begin{array}{l}\text { Суб'єктивне } \\
\text { благополуччя/ } \\
\text { задоволеність }\end{array}$ & $\begin{array}{c}13,98 \pm 3,92 / 15,00 \\
(11,00-18,00)\end{array}$ & $\begin{array}{c}11,18 \pm 4,55 / 11,00 \\
(7,00-14,00)\end{array}$ & $\begin{array}{c}7,95 \pm 4,16 / 6,00 \\
(5,00-10,00)\end{array}$ & 0,000 & 0,000 & 0,000 \\
\hline $\begin{array}{l}\text { Виконання соціальних } \\
\text { ролей }\end{array}$ & $\begin{array}{c}22,09 \pm 3,84 / 23,00 \\
(20,00-25,00)\end{array}$ & $\begin{array}{c}19,15 \pm 5,19 / 19,00 \\
(15,00-23,00)\end{array}$ & $\begin{array}{c}13,98 \pm 5,35 / 12,00 \\
(10,00-19,00)\end{array}$ & 0,000 & 0,000 & 0,000 \\
\hline $\begin{array}{l}\text { Зовнішні життєві } \\
\text { умови }\end{array}$ & $\begin{array}{c}25,16 \pm 3,01 / 26,00 \\
(23,00-27,00)\end{array}$ & $\begin{array}{c}23,00 \pm 4,15 / 24,00 \\
(21,00-26,00)\end{array}$ & $\begin{array}{c}18,88 \pm 5,41 / 20,00 \\
(14,00-23,00)\end{array}$ & 0,000 & 0,000 & 0,000 \\
\hline $\begin{array}{l}\text { Показник якості } \\
\text { життя }\end{array}$ & $\begin{array}{c}6,12 \pm 1,02 / 6,40 \\
(5,40-6,90)\end{array}$ & $\begin{array}{c}5,33 \pm 1,32 / 5,30 \\
(4,30-6,40)\end{array}$ & $\begin{array}{c}4,08 \pm 1,41 / 3,70 \\
(2,80-5,20)\end{array}$ & 0,000 & 0,000 & 0,000 \\
\hline
\end{tabular}

Найнижчі показники ЯЖ виявлені у старшій віковій групі (45 років і старші), найвищі - у молодшій віковій групі (до 30 років). Ця ж тенденція зберігається й при оцінці яЖ фахівцем, причому найвищі показники виявлені у сферах громадської та службової підтримки та соціоемоційної підтримки; у цих сферах вони практично не відрізняються від показників, притаманних психічно здоровим людям, тоді як у сферах психологічного (емоційного) благополуччя, працездатності й загального сприйняття життя показник ЯЖ $\epsilon$ низьким навіть у наймолодшій віковій групі.

Виявлені у дослідженні гендерні відмінності у самооцінці ЯЖ можуть бути пов' язані з особливостями психологічного реагування чоловіків і жінок, зі схильністю останніх до більш емоційного реагування на складні ситуації, більшою чутливістю їх до погіршання якості життя, більшою сенситивністю; натомість, для чоловічої психологічної моделі більш притаманні тенденції до приховування переживань, прагнення показати себе мужнім, небажання виглядати нещасним і знедоленим тощо, що відображається на самооцінці Яж. Оцінка Яж фахівцем у даному випадку більше відповідає фактичній ситуації з показниками депресії: у наших дослідженнях на цьому ж контингенті хворих у чоловіків були виявлені значуще вищі рівні депресії. Водночас, у жінок були виявлені значуще вищі рівні тривожності, що також відображається на оцінці ЯЖ.

Щодо зниження показників ЯЖ з віком, то воно відображає як загальну тенденцію до погір- шання ЯЖ по мірі старіння людини, так і прогредієнтність депресивного процесу, що зазвичай починається у молодому віці й призводить до формування патохарактерологічних рис і стійких змін психіки, що також відображається на оцінках Яж. Крім того, у наших дослідженнях на даному контингенті було показано значуще зростання з віком показників як депресії, так і іншої психопатологічної симптоматики (тривожності, ворожості, соматизації, обсесивно-компульсивної симптоматики, психотизму та інших), що також впливає на Яж.

Дисоціація між самооцінкою ЯЖ та оцінкою яж фахівцем є закономірним наслідком порушень у афективній та когнітивній сферах, асоційованих 3 депресією, зокрема, з тенденцією до песимістичного сприйняття реальності, ідеями самоприниження і самозвинувачення, які відбиваються на оцінці хворими себе, свого мікросоціального середовища та ЯЖ.

Висновки. Хворим на депресивні розлади притаманний низький рівень ЯЖ, при цьому наявна дисоціація між самооцінкою ЯЖ та оцінкою її фахівцем. Жінки, хворі на депресивні розлади, виявили більш низьку самооцінку ЯЖ, порівняно з чоловіками, за всіма ключовими сферами, за винятком сфери духовної реалізації. Оцінка ЯЖ фахівцем, яка виявила нижчі показники у чоловіків, більшою мірою відображає тенденцію до вищих рівнів депресії у чоловіків, водночас, розбіжності у показниках Яж між чоловіками і жінками за більшістю сфер виявилися статистично не значущими. Найточніше самооцінка ЯЖ хворими відповідає оцінці 
Огляди літератури, оригінальні дослідження, поглядн на фахівця за сферою психічного (емоційного) благополуччя, а найменше - за сферами особистісної реалізації та загального сприйняття життя.

3 віком ЯЖ хворих на депресивні розлади суттєво погіршується, що може бути пов' язано як із загальною тенденцією до зниження показників яж з віком, так і впливом психопатологічної симптоматики і прогредієнтністю депресивного процесу.

Виявлені закономірності слід враховувати при розробці лікувально-реабілітаційних та профілактичних заходів для хворих на депресивні розлади.

Перспективи подальших досліджень полягають у створенні комплексних моделей психосоціальної дезадаптації при депресивних розладах з урахуванням соціальних, конституційно-біологічних, клініко-психопатологічних, індивідуальнопсихологічних характеристик, а також розробці сучасних методів раннього прогнозування, лікування та реабілітації при депресивних розладах.

\section{ЛITEPATУРA}

1. The economic burden of adults with major depressive disorder in the United States (2005 and 2010) / P. E. Greenberg, A. A. Fournier, T. Sisitsky, C. T. Pike // J. Clin. Psychiatry. - 2015. - Vol. 76 (2). - P. 155-162.

2. Prevalence and correlates of major depressive disorder: a systematic review / L. Gutiérrez-Rojas, A. Porras-Segovia, H. Dunne, N. Andrade-González // Braz. J. Psychiatry. - 2020. - Vol. 42 (6). - P. 452.

3. Murray C. J. Global, regional, and national incidence, prevalence, and years lived with disability for 354 diseases and injuries for 195 countries and territories, 1990-2017: a systematic analysis for the Global Burden of Disease Study 2017 / C. J. Murray // Lancet. - 2018. Vol. 392. - P. 1789-1858.

4. Malhi G. S. Depression / G. S. Malhi, J. J. Mann // Lancet. - 2018. - Vol. 392. - P. 2299-2312.

5. Fekadu N. Major depressive disorder: pathophysiology and clinical management / N. Fekadu, W. Shibeshi, E. Engidawork // J. Depress. Anxiety. - 2016. - Vol. 6 (1). P. 255-257.

6. Kessing L. V. Does cognitive dysfunction in bipolar disorder qualify as a diagnostic intermediate phenotype? / L. V. Kessing, K. Miskowiak // Front. Psychiatry. 2018. - Vol. 9. - P. 490.

7. Pshuk N. G. Introducing system of psychotherapeutic intervention for family caregivers of patients with endogenous mental disorders / N. G. Pshuk, L. V. Stukan, A. O. Kaminska // Wiad. Lek. - 2018. - Vol. 71 (5). P. 980-985.

\section{REFERENCES}

1. Greenberg, P.E., Fournier, A.A., Sisitsky, T., \& Pike, C.T. (2015). The economic burden of adults with major depressive disorder in the United States (2005 and 2010). J. Clin. Psychiatry, 76 (2), 155-162. Retrieved from: https://doi.org/10.4088/JCP.14m09298

2. Gutiérrez-Rojas, L., Porras-Segovia, A., Dunne, H., \& Andrade-González, N. (2020). Prevalence and correlates of major depressive disorder: a systematic review. Braz. J. Psychiatry, 42(6), 452. Retrieved from: https://doi. org/10.1590/1516-4446-2020-0650

3. Murray, C.J. (2018). Global, regional, and national incidence, prevalence, and years lived with disability for 354 diseases and injuries for 195 countries and territories,
8. Алгоритм оцінки сімейного статусу родини з онкологічним пацієнтом / І. Р. Мухаровська, М.В.Маркова, Т. Г. Кривоніс, І.В.Жулкевич // Вісник соціальної гігієни та організації охорони здоров' я України. - 2020. № 1 (83). - C. 18-23.

9. Markova M. Contents and efficiency measures of psychoeducation in rehabilitation system of patients with bipolar affective disorder / M. Markova, O. Rezunenko, H. Kozhyna // J. Educ. Health Sport. - 2017. - Vol. 7 (3). P. 711-715.

10. Management of treatment-resistant depression in primary care: a mixed-methods study / N. Wiles, A. Taylor, N. Turner [et al.] // Br. J. Gen. Pract. - 2018. - Vol. 68 (675). P. 673-681.

11. Методологічні підходи до вивчення якості життя в гематологічних дослідженнях / І. В. Жулкевич, С. І. Сміян, М. Є. Гаврилюк [та ін.] // Вісник наукових досліджень. - 2000. - № 3. - С. 16-23.

12. Effect of treatments for depression on quality of life: a meta-analysis / S. G. Hofmann, J. Curtiss, J. K. Carpenter, S. Kind // Cogn. Behav. Ther. - 2017. - Vol. 46 (4). P. 265-286.

13. Кривоніс Т. Г. Гендерні особливості прояву клініко-психологічних феноменів у онкологічних пацієнтів / Т. Г. Кривоніс, І. В. Жулкевич // Здобутки клінічної і експериментальної медицини. - 2020. - № 1. - С. 115-119.

14. Критерий качества жизни в психиатрической практике / Н. А. Марута, Т. В. Панько, И. А. Явдак, Е. Е. Семыкина. - Харьков : РИФ Арсис ЛТД, 2004.

1990-2017: a systematic analysis for the Global Burden of Disease Study 2017. Lancet, 392, 1789-1858. Retrieved from: https://doi.org/10.1016/S0140-6736(18)32279-7

4. Malhi, G.S., \& Mann, J.J. (2018). Depression. Lancet, 392, 2299-2312. Retrieved from: https://doi.org/ 10.1016/S0140-6736(18)31948-2

5. Fekadu, N., Shibeshi, W., \& Engidawork, E. (2016). Major depressive disorder: pathophysiology and clinical management. J. Depress. Anxiety, 6 (1), 255-257. Retrieved from: https://doi.org/10.4172/2167-1044.1000255

6. Kessing, L.V., \& Miskowiak, K. (2018). Does cognitive dysfunction in bipolar disorder qualify as a diagnostic intermediate phenotype? Front. Psychiatry, 9, 
Огляди літератури, оригінальні дослідження, погляд на проблему, випадок з практики, короткі повідомлення 490. Retrieved from: https://doi.org/10.3389/fpsyt. 2018.00490

11. Zhulkevych, I.V., Smiian, S.I., Havryliuk, M.Ye., Kmi-

7. Pshuk, N.G., Stukan, L.V., \& Kaminska, A.O. (2018). Introducing system of psychotherapeutic intervention for family caregivers of patients with endogenous mental disorders. Wiad. Lek., 71 (5), 980-985. Retrieved from: https:// ncbi.nlm.nih.gov/pubmed/30176626

8. Mukharovska, I.R., Markova, M.V., Krivonis, T.G., \& Zhulkevych, I.V. (2020). Alhorytm otsinky simeinoho statusu rodyny z onkolohichnym patsiientom [Algorithm for assessment family status of families with cancer patient]. Visnyk sotsialnoi hihiieny ta orhanizatsii okhorony zdorovia Ukrainy - Bulletin of Social Hygiene and Health Protection Organization of Ukraine, 1, 18-23. Retrieved from: https:// doi.org/10.11603/1681-2786.2020.1.11200 [in Ukrainian].

9. Markova, M., Rezunenko, O., \& Kozhyna, H. (2017). Contents and efficiency measures of psychoeducation in rehabilitation system of patients with bipolar affective disorder. J. Educ. Health Sport., 7, 711-715. Retrieved from: https://doi.org/10.5281/zenodo.830020

10. Wiles, N., Taylor, A., Turner, N., Barnes, M., Campbell, J., Lewis, G., \& Kessler, D. (2018). Management of treatment-resistant depression in primary care: a mixedmethods study. Br. J. Gen. Pract., 68 (675), 673-681. Retrieved from: https://doi.org/10.3399 / bjgp18X699053

ta, H.H., Kramar, L.T., \& Korchynska, R.M. (2000). Metodolohichni pidkhody do vyvchennia yakosti zhyttia v hematolohichnykh doslidzhenniakh [Methodological approaches to the study of quality of life in hematological research]. Visnyk naukovykh doslidzhen - Bulletin of Scientific Researches, 3, 16-23 [in Ukrainian].

12. Hofmann, S.G., Curtiss, J., Carpenter, J.K., \& Kind, S. (2017). Effect of treatments for depression on quality of life: a meta-analysis. Cogn. Behav. Ther., 46 (4), 265-286. Retrieved from: https://doi.org/10.1080/165060 73.2017.1304445

13. Krivonis, T.G., \& Zhulkevych, I.V. (2020). Henderni osoblyvosti proiavu kliniko-psykholohichnykh fenomeniv u onkolohichnykh patsiientiv [Gender features of clinicalpsychological phenomena in cancer patients]. Zdobutky klinichnoi i eksperymentalnoi medytsyny-Achievements of Clinical and Experimental Medicine, 1, 115-119. Retrieved from: https://doi.org/10.11603/1811-2471.2020.v.i1. 11078 [in Ukrainian].

14. Maruta, N.A., Panko, T.V., Yavdak, I.A., \& Semykina, E.E. (2004). Kriteriy kachestva zhizni v psikhiatricheskoy praktike [Quality of life criterion in psychiatric practice]. Kharkov: RIF Arsis Ltd [in Russian].

\section{ГЕНДЕРНЫЕ И ВОЗРАСТНЫЕ ОСОБЕННОСТИ КАЧЕСТВА ЖИЗНИ У БОЛЬНЫХ ДЕПРЕССИВНЫМИ РАССТРОЙСТВАМИ}

\section{Винницкий национальный медицинский университет имени Н. И. Пирогова}

๑А. А. Белов

РЕзюМЕ. Цель - исследовать особенности качества жизни больных депрессивными расстройствами с учетом гендерных и возрастных особенностей.

Материал и методы. Клинически обследовано 107 мужчин и 138 женщин, больных депрессивными расстройствами эндогенного характера, с использованием методики оценки качества жизни Mezzich et al. в адаптации Н. А. Маруты.

Результаты. Для больных депрессивными расстройствами характерны низкая самооценка качества жизни (КЖ), особенно по сферам психологического благополучия, общего восприятия жизни, работоспособности, личностной реализации и физического благополучия. У женщин выявлены низкие показатели КЖ по сферам физического благополучия, психологического благополучия, самообслуживания и независимости действий, работоспособности, межличностного взаимодействия и социоэмоциональной поддержки, а также по интегральным сферами субъективного благополучия/удовлетворенности и выполнения социальных ролей, и интегральным показателям КЖ. Оценка КЖ специалистом обнаружила высокие показатели КЖ у мужчин, при этом значимыми различия были только по сферам духовной реализации и общего восприятия жизни. Оценка КЖ специалистом была в среднем в 1,5 раза выше, чем самооценка больными. С возрастом показатели КЖ по всем сферам ухудшаются.

Выводы. Депрессия сопровождается выраженным снижением КЖ по всем сферам, которое субъективно тяжелее воспринимается женщинами, но объективно более выражено у мужчин; это ухудшение становится более выраженным с возрастом.

КЛЮЧЕВЫЕ СЛОВА: депрессивные расстройства; качество жизни; гендерные; возрастные особенности. 


\section{Pyrohov Vinnytsia National Medical University}

SUMMARY. The aim - to investigate the features of the quality of life of patients with depressive disorders, taking into account gender and age characteristics.

Material and Methods. 107 men and 138 women with endogenous depressive disorders were clinically examined using quality assessment methods Mezzich et al. in the adaptation of N.O. Maruta.

Results. Patients with depressive disorders are characterized by low self-esteem of QoL, especially in the areas of psychological well-being, general perception of life, ability to work, personal realization and physical well-being. Women have lower QoL scores in the areas of physical well-being, psychological well-being, self-care and independence, ability to work, interpersonal interaction and socio-emotional support, as well as in the integrated areas of subjective well-being / satisfaction and fulfillment of social roles. The assessment of QoL by a specialist revealed higher rates of QoL in men, with significant differences were only in the areas of spiritual realization and general perception of life. The assessment of QoL by a specialist is on average 1.5 times higher than the self-assessment of patients. With age, QoL indicators in all areas deteriorate.

Conclusions. Depression is accompanied by a pronounced decrease in QoL in all areas, which is subjectively more difficult for women, but objectively more pronounced in men; this deterioration becomes more pronounced with age.

KEY WORDS: depressive disorders; quality of life; gender; age features.

Отримано 13.01.2021 